\title{
ДОКТРИНАЛЬНО-ПРАВОВЕ ТА ПРАКТИЧНЕ ОСМИСЛЕННЯ ПРОБЛЕМ РЕАЛІЗАЦІЇ ПРАВА ЗАГАЛЬНОГО ВИКОРИСТАННЯ ОБ'ЄКТІВ ТВАРИННОГО СВІТУ
}

Шеховцов В. В.

У науковій статmі досліджено аксіологічну сутність та юридичну природу права загального користування об'єктами тваринного світу як природнього та невідчужуваного права кожної людини. Наголошено на тому, що це право не дароване та не санкціоноване державою, а належить людині від народження завдяки іï сприйняття як частини природи та їі соціальнобіологічної сутності. На основі аналізу фауністичного законодавства автор акцентує на необхідності створення чіткого правового механізму реалізації всіх можливостей користування об'єктами тваринного світу в різних, передбачених законом, цілях. Аналізується судова практика щодо реалізації права загального користування об'єктами тваринного світу.

Ключові слова: тваринний світ, правого загального користування об'єктами тваринного світу, фауністичне законодавство, охорона та використання тваринного світу.

В научной статье исследована аксиологическая сущность права общего пользования объектами животного мира как природного и неотделимого права каждого человека. Отмечено, что это право не подарено и не санкционировано государством, а принадлежит человеку от рождения в силу его восприятия как части природы и его социально-биологической сущности. На основе анализа фаунистического законодательства автор акцентирует на необходимости создания четкого правового механизма реализации всех возможностей использования объектов животного мира в разных, предусмотренных законом, целях. Анализируется судебная практика в сфере реализации права общего пользования объектами животного мира.

Ключевые слова: животный мир, право общего пользования объектами животного мира, фаунистическое законодательство, охрана и использование животного мира.

Shekhovtsov V. V. Doctrinal, legal and practical conceptualization of implementation difficulties of the right of wildlife general usage

In the modern context of human civilization development, the meeting of requirements to commune with

() Шеховцов В. В., 2020 the nature and its richness for satisfaction of wide range of needs (predominantly intangible one's) has become institutionally formalized character, and realization of this needs is objectifying by establishing a system of legal provisions that determine the fundamental principles and procedure for execution of right of wildlife general usage. Thereby, the article is devoted to examination of the axiological substance and legal nature of right of wildlife general usage as a natural and inherent right of each person. The task of the state is only to ensure the legal existence of such a right and to create of appropriate legal guarantees for its smooth and effective implementation. However, this right isn't absolute whereas certain restrictions on its implementation are imposed at the legislation in order to ensure the public environmental interest. On the basis of the performed research, the author has emphasized on the necessity to create an unambiguous legal mechanism for the realization of all opportunities for wildlife general usage for various purposes provided by the law. There has been established that the violation of right of wildlife general usage has an ambivalent manifestation. On the one hand, natural resource users abridge citizens' access to exercising their inherent right. On the other hand, the citizens themselves neglect the requirements and legal rules of realization of their natural right, which results in the application of legal responsibility. There has been summarized that in modern social and economic as well as political transformations, the realization of right of wildlife general usage is complicated by the actualization of contractual relations within the framework of environmental law. For instance, tenants of waterbodies stand in the way to citizens from engaging in recreational and sport fishing contrary to the requirements of environmental legislation.

Key words: wildlife, animal world, right of wildlife general usage, faunistic legislation, protection and usage of animal world.

Людство на Землі та жива й нежива природа становлять дещо єдине, що живе за загальними законами природи.

B.I. Вернадський

Постановка проблеми та іï актуальність. У процесі еволюційного розвитку із накопиченням 


\section{Проблеми екологічного законодавства}

емпіричного досвіду світоглядно-ціннісні орієнтири та уявлення людини щодо залежності від якості і стану природного довкілля та його компонентів поступово прогресували. Об'єктивні реалії сучасної системи природно-людських відносин демонструють, що як би людина не намагалась підкорити собі природу в абсолютному вимірі, врешті-решт саме людина залишається в підпорядкуванні природи, бувши залежною від природних умов та її об'єктивних законів.

Відносини людини та природи мають давні витоки й виникають задовго до появи соціально-правової системи та правових регуляторів суспільних відносин, адже з перших сторінок історії людина відчувала потребу у використанні природних благ для стабілізації свого духовно-морального та фізичного стану.

За сучасних умов розвитку людської цивілізації забезпечення потреби у спілкуванні із природою та іï багатствами для задоволення широкого спектру потреб (переважно нематеріального характеру) набуло інституціонального формалізованого характеру, а реалізація зазначеної потреби об'єктивується за допомогою встановлення системи правових норм, які визначають фундаментальні засади й порядок здійснення права загального природокористування, зокрема права загального користування об'єктами тваринного світу.

Аналіз останніх досліджень і публікацій. На доктринальному рівні проблема забезпечення права загального природокористування, зокрема загального користування об'єктами тваринного світу, була предметом наукових пошуків у працях таких учених, як: В.І. Андрейцев, Г.В. Анісімова, А.П. Гетьман, І.І. Каракаш, Н.Р. Кобецька, В.Л. Мунтян, С.В. Разметаєв, В.С. Шахов, Ю.С. Шемшученко, тощо. Окремі аспекти пошуку оптимальних шляхів забезпечення прав та інтересів учасників фауністичних правовідносин під час здійснення права загального користування об'єктами тваринного світу вже були предметом дослідження автора цієї публікації і, відповідно, інша частина комплексного питання забезпечення реалізації права загального користування об'єктами тваринного світу крізь призму теоретичних та практичних проблем знаходить відображення в цій статті.

Метою статті є доктринально-правовий аналіз та висвітлення онтологічної основи загального користування об'єктами тваринного світу, а також висвітлення актуальних правових проблем забезпечення зазначеного права на підставі практики реалізації фауністичного законодавства.
Виклад основного матеріалу. Аксіологічна сутність права загального природокористування, на відміну від господарського, комерційного використання природних ресурсів, відображає власне екологічні потреби та інтереси людини, які пов'язані передусім із необхідністю збереження людини як біологічного та соціального організму, а не з використанням природи з метою задоволення матеріальних та інших подібних потреб [1, с. 99], що створює, зі свого боку, концептуальні засади для визначення належності досліджуваного права до життєво важливих [1, с. 100] та природно-соціальних прав, які ґрунтуються на сутності людини як соціально-біологічної істоти [2, с. 401].

До того ж учені виділяють як принцип права природокористування - пріоритет загального природокористування, сутністю якого $€$ першорядне відновлення потреб у загальному природокористуванні завдяки природним ресурсам [3, с. 97].

Право загального природокористування $\epsilon$ особливою правовою конструкцією з тільки їй властивим змістом, в основі якої лежить нерозривний природний зв'язок людини і природи. Право загального природокористування виникає у зв'язку з наявністю в людини потреби в використанні об'єктів тваринного світу як природної умови ії існування.

У цьому сенсі право на безпечне для життя і здоров'я довкілля і право загального природокористування мають спільне походження відповідних інтересів і загальну сферу дії - спрямованість на задоволення природних, життєзабезпечуючих потреб. Водночас, як акцентує В.Л. Бредіхіна, в основі зазначеного суб'єктивного права (права на безпечне для життя і здоров'я довкілля) лежить певний екологічний інтерес, що, з одного боку, становить начебто його мотивовану частину й виражається в необхідності підтримки прийнятної, безпечної для життя і здоров'я громадян якості довкілля. 3 іншого боку, право на безпечне для життя і здоров'я середовище слугує формою реалізації цього інтересу [4, с. 20].

Проте право загального природокористування і право на безпечне довкілля можна розмежувати теоретично. Їх відмінності полягають, зокрема, в такому: суть права на безпечне для життя і здоров'я довкілля - як природного середовища, а головне у праві загального природокористування - у свободі доступу до нього; право на безпечне для життя і здоров'я довкілля реалізується безперервно й постійно, а деякі види права загального природокористування можуть бути перенесені в часі, й за необхідності - замінені 
користуванням об'єктами штучного походження, що принципово неможливо для права на безпечне для життя і здоров'я довкілля; право загального природокористування може бути обмежене (наприклад, перебування в лісах, на водоймах) із підстав, зазначених у законі, а можливість обмеження права - на безпечне для життя і здоров'я довкілля законом не передбачена.

Право на безпечне довкілля і право загального природокористування мають чимало спільного, особливо у сфері рекреаційного природокористування, найбільш соціально значимого й залежного від якісного стану природних об'єктів, комплексів та екосистем, порушення якого може в певних випадках кваліфікуватися як порушення права на безпечне довкілля.

Правові засади права загального користування об'єктами тваринного світу визначені в екологічному законодавстві та знаходять безпосередню юридичну деталізацію в нормативно-правових актах фауністичного спрямування. Так, ст. 16 Закону України «Про тваринний світ» закріплює правову гарантію права безоплатного загального використання об'єктів тваринного світу для задоволення життєво необхідних потреб, а також визначає правила та перелічує можливі способи реалізації цього права. Загальні засади, котрі відобразились у зазначеній правовій нормі, передбачають, що таке право здійснюється на безоплатній основі та без вилучення об'єктів тваринного світу із природного середовища (за винятком любительського i спортивного рибальства у водних об'єктах загального користування в межах установлених законодавством обсягів безоплатного вилову). У порядку загального користування об'єктами тваринного світу здійснюється використання корисних властивостей життєдіяльності тварин - природних санітарів середовища, запилювачів рослин тощо, а також використання об'єктів тваринного світу з науковою, культурно-освітньою, виховною, естетичною тощо метою, не заборонених законом [5].

Проте право загальнодоступного користування об'єктами тваринного світу не $є$ за своєю соціально-правовою сутністю абсолютним. Науково-теоретична концепція кореляції прав та обов'язків (зокрема екологічних) детермінує потребу законодавчого встановлення обмежень під час реалізації громадянами права користування об'єктами тваринного світу в порядку загального використання. Зміст та сутність таких законодавчих обмежень зумовлюється публічним екологічним інтересом, який має амбівалентний характер застосування у відносинах загального природокористування.

По-перше, інтерпретація публічного екологічного інтересу зводиться до необхідності регламентації діяльності із загального та безперешкодного використання тваринного світу, вилучення корисних властивостей диких тварин шляхом установлення обмежень у способах та засобах його реалізації. Водночас основоположною кінцевою метою встановлення таких обмежень $€$ передусім збереження всього генофонду тваринного світу, його кількісно-якісного біологічного стану як невід'ємного компонента єдиної екосистеми, який виконує важливі еколого-регулюючі функції. Саме тому під час здійснення загального користування об'єктами тваринного світу забороняється знищення тварин, руйнування їхнього житла та інших споруд (нір, хаток, лігв, гнізд, мурашників, бобрових загат тощо), порушення середовища існування тварин і погіршення умов їх розмноження [5].

По-друге, інтенсифікація залучення в господарський оборот природних ресурсів тваринного світу та посилення договірних засад в екологічному праві, на що в еколого-правовій науці вчені особливо звертали увагу (Г.В. Анісімова, М.В. Краснова), створює принципову необхідність у визначенні якісно нових методологічних підходів до оптимального поєднання інтересів усіх учасників екологічних правовідносин, що вимагає правової визначеності в чинному екологічному законодавстві.

Як слушно зазначає Г.В. Анісімова, залучення природних ресурсів до цивільного обігу висуває проблему вільного доступу громадян до природних об'єктів, що обмежує майнові права інших суб'єктів. Власник стає зобов' язаним користуватись і розпоряджатись об'єктами права власності, дотримуючись публічних екологічних інтересів [6, с. 4], тим самим реалізуючи концепцію екологічного імперативу як правового механізму подолання консонансу між інтересами різних соціальних груп.

у найбільш узагальненому вигляді, екологічний імператив репрезентується сукупністю вимог до діяльності людини у природному середовищі, що спрямовані на попередження та мінімізацію завдання шкоди довкіллю, відновлення балансу на планеті. Сукупність таких вимог містить як систему неінституціональних (норми моралі, цінності, які $\epsilon$ духовною основою негативної суспільної оцінки завдання шкоди довкіллю), так i інституціональних регуляцій (правові норми та інститути, що регулюють суспільні відносини) [7, с. 109]. 


\section{Проблеми \\ екологічного законодавства}

Тому, як проміжний, можна зробити висновок, що право загального доступу до об'єктів тваринного світу $\epsilon$ природним та невідчужуваним правом кожної людини, який належить від її народження та через їі біологічно-соціальну сутність. Це право не санкціоноване та не дароване людині будьяким політико-правовим утворенням або сувереном (тобто не $\epsilon$ правом позитивним), оскільки його онтологічне походження зумовлене інстинктами людини як поведінкового акту, створеного внаслідок тривалої еволюції, що спрямований на забезпечення життєвих функцій й самого функціонування кожної людини [8, с. 454], а також об'єктивної потреби у спілкуванні із живою та неживою природою для стабілізації естетичних, виховних, пізнавальних, культурних та оздоровчо-рекреаційних благ. Потреба людини впливає на її свідомість і спонукає до активізації діяльності до їі задоволення, тобто впливає на формування інтересу (екологічного). На цьому наголошував свого часу й В.К. Попов, який зазначав, що змістом цього інтересу $\epsilon$ сукупність соціальних і біологічних потреб людини, які визначені самою природою й виявляються в необхідності споживання безпечних для іiі життя i здоров'я природних ресурсів [9, с. 15-16].

Завдання держави полягає лише в нормативно-правому забезпеченні такого права та створення належних правових гарантій його безперешкодної й ефективної реалізації (один з аспектів екологічної функції держави).

Незважаючи на те, що сучасне екологічне та фауністичне, як його частина, законодавство декларує можливість громадянам реалізувати природне право безоплатного загального користування об'єктами тваринного світу, питання щодо створення дієвого правового механізму, який би визначав порядок його здійснення, все ще залишається актуальним. Наприклад, законом надається право використовувати об' єкти тваринного світу в порядку загального використання для естетичної мети або ж використовувати корисні властивості життєдіяльності тварин, однак чинна система нормативно-правового забезпечення цієі можливості не передбачає юридичного механізму (процедури) реалізації такого права. 3 огляду на вказане $\epsilon$ сенс звернутись до практики Європейського суду із прав людини, який у своєму рішенні у справi Yvonne van Duyn v. Home Office зазначив, що «принцип юридичної визначеності означає, що зацікавлені особи повинні могти покладатись на зобов'язання, взяті державою, навіть якщо такі зобов'язання містяться в законодавчому акті, який загалом не має автоматичної прямої дії». 3 огляду на принцип юридичної визначеності держава не може посилатись на відсутність певного нормативного акту, який би визначав механізм реалізації прав та свобод громадян, закріплених у конституції чи інших актах. На цю практику національні суді останнім часом часто посилаються у вирішенні питань, пов'язаних із порушенням екологічного законодавства (наприклад, у Рішенні Одеського окружного адміністративного суду від 24 липня 2020 року [10]).

Чинне екологічне законодавство дозволяє зводити нанівець право загального природокористування громадян навіть не власникам, а користувачам (орендарям) природних об'єктів [11, с. 68]. Стаття 47 Водного кодексу України, у якій, зокрема, встановлено, що загальне водокористування здійснюється громадянами для задоволення їх потреб (купання, плавання на човнах, любительське і спортивне рибальство, водопій тварин, забір води з водних об'єктів без застосування споруд або технічних пристроїв, а також криниць) безкоштовно, без закріплення водних об'єктів за окремими особами та без надання відповідних дозволів не додала ясності в досліджуване питання [12]. Законодавець указав на можливість любительського чи спортивного рибальства в порядку загального водокористування та користування тваринним світом. I зрозумілим $\epsilon$ те, що давати можливість використовувати об'єкти тваринного світу, зокрема рибу, на праві загального природокористування можна тільки на об'єктах державної або комунальної власності. Приватний власник управі самостійно визначати коло осіб, час, обсяг використання його власності.

На наше переконання, для визначення права власності на об'єкти тваринного світу, які перебувають у водоймі одночасно з об'єктами аквакультури, необхідно враховувати режим цих тварин, який існував до передачі водного об'єкта в користування. 3 огляду на аналіз нормативних актів, що регулюють облік та звітність у галузі аквакультури, суб'єкт аквакультури зобов'язаний повною мірою відображати у своїй документації види, кількість, вікові групи, масу та інші характеристики кожного виду об'єкта аквакультури.

Отже, стверджувати про наявність у суб'єкта аквакультури права власності на всю рибу у водоймі, яка була йому надана, немає підстав. Відповідно, він не має права встановлювати обмеження щодо використання місцевих видів риб під час здійсненні загального природокористування. 
До того ж типова форма договору оренди водного об'єкта однією з підстав для розірвання такого договору передбачає встановлення заборони загального водокористування, до якого, відповідно до ст. 47 Водного кодексу України, належить і спортивне та любительське рибальство, що дозволяє резюмувати про пріоритет загального природокористування в системі екологічних правовідносин.

До того ж в еколого-правовій науці $\epsilon$ й діаметрально протилежні погляди на перспективу ефективного збалансування публічних та приватних інтересів суб'єктів екологічного права. Наприклад, М.С. Костюченко акцентує на тому, що наявність закріпленого у ВК України права загального водокористування у вигляді любительського і спортивного рибальства вступає у пряме протиріччя із правом орендаря водного об'єкта на використання водного об'єкта для рибогосподарських потреб, зокрема права на отримання матеріальної вигоди від продажу належних орендарю водного об'єкту водних живих ресурсів. Задля збалансування прав зазначених категорій суб'єктів він пропонує запровадити механізм компенсації орендареві водного об'єкта, який використовується для рибогосподарських потреб, фактичної вартості виловленої риби та інших водних живих ресурсів, яка визначатиметься водокористувачем за погодженням з органом, який надав водний об'єкт в оренду [13, с. 140]. Однак така позиція видається дещо сумнівною та спірною, оскільки вона не враховує соціальної функції та онтологічно-ідейної сутності права загального використання об'єктів тваринного світу.

По-перше, як уже зазначалось, право загального природокористування має пріоритет над правом спеціального використання природних ресурсів; по-друге, встановлення механізму компенсації фактичної вартості виловленої риби нівелюватиме загальні засади здійснення загального природокористування (доступності та безоплатності, оскільки його реалізація тією чи іншою мірою буде залежати від матеріального стану природокористувача); по-третє, запропоновані зміни до законодавства не враховують й інші правові норми, визначені не лише Водним кодексом, але й Законом України «Про тваринний світ», які передбачають обмеження права загального користування об'єктами тваринного світу в чітко визначених законом випадках (передусім для забезпечення загальнонаціонального екологічного інтересу охорона життя і здоров'я громадян, а також збереження й відтворення тваринного світу).
Якщо ж апелювати до судової практики, то в питанні збалансування інтересів публічних (народ України) та приватних суб'єктів у контексті забезпечення права загального користування об'єктами тваринного світу (зокрема аквакультури) вона $\epsilon$ неоднозначною. В одних випадках суди пов'язують установлення правил та, відповідно, обмежень загального водокористування (зокрема здійснення любительського або спортивного рибальства) орендарями водних об'єктів із їх процедурним узгодженням з органом, котрий надав такий об'єкт в оренду.

Так, до Львівського окружного адміністративного суду звернувся орендар водного об'єкта з вимогою визнати протиправною бездіяльність районної державної адміністрації (далі - РДА) щодо прийняття рішення про заборону здійснення любительського та спортивного рибальства. Як обґрунтування позовних вимог представник позивача пояснив, що між позивачем та РДА укладено договір оренди земельної ділянки водного фонду для рибогосподарських потреб. Судом було встановлено, що Рішенням сільської ради Перемишлянського району Львівської області надано дозвіл на виготовлення технічної документації із землеустрою щодо встановлення меж земельної ділянки в натурі з подальшою передачею в оренду терміном на 25 років позивачеві для рибогосподарських потреб. Згідно з п. 30.6 Договору оренди орендодавець зобов'язаний забезпечити жителям району вільний доступ для купання. Постановою Львівського окружного адміністративного суду від 21 листопада 2014 року у справі №813/4672/14 суд дійшов висновку, що законодавством передбачено надання водних об'єктів в оренду без обмеження права загального водокористування обов'язок орендаря забезпечити доступ до загального водокористування. Умови загального водокористування можуть бути встановлені водокористувачем лише за погодженням з органом, який надав водний об'єкт в оренду. Якщо ж такі умови не встановлені, загальне водокористування визнається дозволеним без обмежень. Установлення ж заборони загального водокористування $\epsilon$ однією з підстав для розірвання договору оренди (шрифт наш - В. Шеховцов) [14].

В іншій справі Другий апеляційний адміністративний суд постановою від 16 квітня 2019 року скасував рішення Сумського окружного адміністративного суду у справі за позовом приватного сільськогосподарського підприємства «Агрофірма Луч» до Державного агентства водних ресурсів про визнання відмови у видачі дозволу на спеціальне 


\section{Проблеми екологічного законодавства}

водокористування протиправною та зобов'язання вчинити певні дії. В суді відповідач обґрунтував прийняття рішення про відмову у видачі зазначеного дозволу, зокрема через неврахування вимог ст. 51 Водного кодексу України, зокрема в частині узгодження договору оренди з Типовим договором оренди водних об'єктів, затвердженого постановою Кабінету Міністрів України від 29.05.2013 р. № 420, передбачення позивачем місць для безоплатного забезпечення права громадян на здійснення любительського та спортивного рибальства в порядку загального водокористування. Не погодившись із рішенням суду першої інстанції, приватне сільськогосподарське підприємство звернулось з апеляційною скаргою, яку було задоволено частково й зобов'язано Держводагенство повторно розглянути заяву позивача щодо видачі дозволу на спеціальне використання водного об'єкта. Суд апеляційної інстанції не взяв до уваги посилання відповідача щодо обмеження прав громадян у здійсненні загального водокористування, а головним аргументом для часткового задоволення апеляційної скарги навів той факт, що правовстановлюючим документом, який дає апелянту право на користування водним об'єктом - ставком, є Договір оренди земельної ділянки з розташованим на ній водним об'єктом від 01.11.2007 року, який на мить його укладення відповідав усім вимогам законодавства щодо змісту, форми та погодження [15].

Варто зазначити й те, що порушення фауністичного законодавства у сфері правового забезпечення загального користування тваринним світом відбувається не лише приватними суб'єктами, але й самі громадяни нехтують встановленими в законодавстві вимогами та правилами реалізації свого природного права загальнодоступності до природних ресурсів, що спричинює застосування до них заходів державно-правового впливу - настання юридичної відповідальності (адміністративної чи кримінальної). Водночас аналіз судової практики засвідчує, що найбільш розповсюдженими $\epsilon$ випадки порушення правил любительського та спортивного рибальства шляхом його здійснення забороненими знаряддями, в заборонений час на заборонені види й із перевищенням обсягів безкоштовного вилову риби. Так, вироком Куп'янського міськрайонного суду Харківської області громадянина було визнано винним у скоєнні умисного незаконного зайняття рибним добувним промислом та засуджено до покарання у вигляді обмеження волі на строк 1 рік та 6 місяців. Суд установив, що особою було здійснено незаконний рибний промисел забороненим знаряддям лову на цінні види риб, а тому дійшов висновку про порушення вимог використання, відтворення й охорони водних живих біоресурсів та завдання рибному господарству України значної шкоди [16].

Висновки. Отже, теоретико-правове дослідження права загального використання об'єктів тваринного світу дозволяє сформулювати такі висновки:

1. Осмислення сутності загального користування об'єктами тваринного світу як суб'єктивного права особи ґрунтується на його забезпеченні нормальної життєдіяльності людини та їі існування загалом. У зв'язку із цим право загального користування об'єктами тваринного світу варто розглядати передусім як природне та невідчужуване від людської особистості право, яке не санкціоноване державою, а належить людині завдяки ії соціально-біологічній сутності.

2. Правове забезпечення загальнодоступної та безперешкодної можливості доступу кожної людини до об'єктів тваринного світу на сьогодні гарантується чинним фауністичним законодавством, проте розроблення чіткого правового механізму реалізації таких можливостей крізь призму процедурно-процесуального аспекту все ще залишається актуальним питанням. Крім того, окремі складники досліджуваного права мають різний ступінь правового врегулювання, що $\epsilon$ неприпустимим із позиції принципу верховенства права та юридичної визначеності (наприклад, фауністичне законодавство досить детально регулює правила здійснення любительського та спортивного рибальства, в той час як реалізація цього права, наприклад, в естетичних або наукових цілях, залишається без належного правового врегулювання).

3. Реалізація права загального користування об'єктами тваринного світу за сучасних соціально-економічних та політичних трансформацій ускладнюється актуалізацією договірних правовідносин у межах екологічного права. Наприклад, орендарі водних об'єктів усупереч вимогам екологічного законодавства перешкоджають здійсненню громадянами любительського та спортивного рибальства, що у статті проілюстровано судовою практикою.

4. Інший аспект порушення права загального користування об'єктами тваринного світу відбувається самими громадянами, які не дотримуються встановлених правил щодо способів та засобів реалізації їх природного права на доступ до природних ресурсів тваринного світу. Тому сучасна 
концепція повинна будуватись на підвищенні рівня усвідомленості громадян про те, що людина $\epsilon$ частиною природи, а тому використовуючи природні багатства в нераціональний та такий, що негативно впливає на кількісно-якісний стан природи спосіб, вона перешкоджає передусім своєму безпечному життю та життю майбутніх поколінь.

\section{Література}

1. Кобецька Н.Р. Сутність і місце права загального природокористування в системі екологічного права. Екологічне право України. 2016. № 1-2. С. 99-100.

2. Анісімова Г.В. Теоретичні засади розвитку екологічного законодавства в контексті природно-правової доктрини : монографія. Харків : Право, 2019. 672 c.

3. Котеньов О.Г. Принципи права на природокористування : дис. ... канд. юрид. наук : 12.00.06. Харків, 2016. 228 с.

4. Бредіхіна В.Л. Конституційні засади права громадян на безпечне природне довкілля / за ред. проф. М.В. Шульги : монографія. Харків : Видавець ФОП Вапнярчук Н.М., 2008. 168 с.

5. Про тваринний світ: Закон України від 13.12.2001 р. № 2894-III. Голос України. 2002. 16 січ. (№ 9).

6. Анісімова Г.В. Законодавчі проблеми забезпечення права загального природокористування. Теорія і практика правознавства: електрон. наук. фах. вид. Нац. ун-ту «Юрид. акад. України ім. Ярослава Мудрого». Харків, 2013. Вип. 1. URL: http://dspace.nlu.edu.ua/handle/123456789/3695.

7. Мирошниченко А.И. Экологический интерес и механизм его защиты как объект теоретико-правового исследования. Философия права. 2010. № 6. С. 107-110.

8. Философия : учебник / О.Г. Данильян, В.М. Тараненко. Харьков : Право, 2013. 496 с.
9. Попов В.К. Право и материальные интересы в межхозяйственной кооперации. Харьков : Высшая школа, 1983. 169 с.

10. Рішення Одеського окружного адміністративного суду від 24 липня 2020 року у справі № 420/3168/20. URL: http://reyestr.court.gov.ua/ Review/90596471 (дата звернення 08.08.2020р.).

11. Шахов В.С. Стан та перспективи розвитку інституту права загального природокористування в сучасному екологічному законодавстві. Актуальні питання кодифікації екологічного законодавства України : 36. тез наук. доп. учасн. «круглого столу», 9 листоп. 2012 р. / Нац. ун-т. «Юрид. акад. України ім. Ярослава Мудрого». Харків, 2012. С. 67-69.

12. Водний кодекс України: Закон України від 6 червня 1995 р. № 213/95-ВР. (1995). Відомості Верховної Ради України, 1995. № 24, Ст. 189.

13. Костюченко М.С. Правове регулювання оренди водних об'єктів в Україні : дис. ... канд. юрид. наук : 12.00.06 / Нац. юрид. ун-т ім. Ярослава Мудрого. Харків, 2018. 220 с.

14. Постанова Львівського окружного адміністративного суду від 21 листопада 2014 р. у справi № 813/4672/14. URL: http://reyestr.court.gov.ua/ Review/41588165 (дата звернення 09.08.2020 p).

15. Постанова Другого апеляційного адміністративного суду від 16 квітня 2019 р. у справі № 480/3922/18. URL: http://reyestr.court.gov.ua/ Review/81333122 (дата звернення 09.08.2020 р).

16. Вирок Куп'янського міськрайонного суду Харківської області від 24 березня 2016 р. у справі № 628/3998/15-к. URL: http://reyestr.court.gov.ua/ Review/56693108 (дата звернення 09.08.2020р.).

Шеховцов В. В., кандидат юридичних наук, доцент, доцент кафедри екологічного права Національного юридичного університету імені Ярослава Мудрого 